\title{
ROLA RADY RODZICÓW W SKUTECZNYM ZARZĄDZANIU SZKOŁĄ PUBLICZNĄ
}

\section{Abstract \\ The Role of Parents' Council in Effective Management of a Public School}

School is a specific public organization. Its difference from other organizations is, among other things, that it brings together specific and diverse stakeholders: students, parents and employees. The implementation of the goals of such an organization depends to a large extent on the director of the educational institution. The conceptual and social skills of the person managing the school have a significant impact on the formation of correct relationships in a diverse environment.

The article attempts to draw attention to the potentially large role of parents' council in managing a public school. The competences of the parents' council were emphasized while showing areas of cooperation with the school's director.

Key words: management in education, management, cooperation, partnership, stakeholders.

\section{Streszczenie}

Szkoła jest specyficzną organizacją publiczną. Jej odmienność od innych organizacji polega między innymi na tym, że skupia ona szczególnych i różnorodnych interesariuszy: uczniów, rodziców oraz pracowników. Realizacja celów tak zbudowanej organizacji zależy w znacznym stopniu od dyrektora placówki oświatowej. Umiejętności koncepcyjne i społeczne osoby kierującej szkołą mają znaczny wpływ na kształtowanie się poprawnych relacji w zróżnicowanym środowisku.

W artykule starano się zwrócić uwagę na potencjalnie dużą rolę rady rodziców w zarządzaniu szkołą publiczną. Podkreślono kompetencje rady, pokazując jednocześnie obszary współpracy z dyrektorem szkoły.

Słowa kluczowe: zarządzanie w oświacie, kierowanie, współpraca/współdziałanie, interesariusze. 


\section{Wstęp}

Rozwijające się technologie informacyjne, globalizacja, budowanie gospodarki opartej na wiedzy - to czynniki wymagające dużej elastyczności i szybkiego dostosowywania się młodego człowieka do dynamicznie zmieniającego się otoczenia. Szczególną rolę w tym procesie przypisuje się edukacji, która poprzez kształcenie, wychowywanie i kształtowanie postawy młodych ludzi umożliwia im zdobywanie wiedzy i umiejętności, mogących w przyszłości skutkować trafnymi decyzjami dotyczącymi własnego rozwoju i kariery.

Edukacja dzieci i młodzieży jest obszarem, którym najbardziej zainteresowani są rodzice. Stanowi ona istotny element wychowania każdego dziecka. Rodzice, kierując się wyborem szkoły dla swojego dziecka, biorą pod uwagę nie tylko jakość nauczania, ale też zwracają szczególną uwagę na relacje wewnętrzne panujące w placówce oraz przekazywane przez nią wartości. Choć wydawać by się mogło, że priorytetem wyboru rodziców staje się zawsze jakość nauczania, to jednak można zauważyć, że takie czynniki jak klimat szkoły i przekazywane wartości stanowią istotne kryterium wyboru placówki oświatowej. Bardzo często rodzice, decydując o edukacji dziecka, stawiają na tej samej pozycji jakość nauczania w szkole oraz kształtowanie osobowości ucznia, budowanie właściwych postaw i zachowań dziecka, mając nadzieję, że takie działania szkoły przyczynią się do uspołecznienia młodego człowieka, a przez to ułatwią absolwentowi zdefiniowanie jego przyszłego miejsca w społeczeństwie. Rodzice, dokonując wyboru szkoły, oczekują od placówki edukacyjnej wsparcia w procesie wychowania swoich dzieci, dlatego też można powiedzieć, że to właśnie rodzice są istotnie zainteresowani wszystkimi działaniami, jakie podejmuje wybrana przez nich placówka. Znowelizowana ustawa o systemie oświaty daje szansę rodzicom na współpracę ze szkołą poprzez obligatoryjne funkcjonowanie w każdej z nich rady rodziców.

Celem artykułu jest uświadomienie korzyści płynących z funkcjonowania rady rodziców w placówce oświatowej.

Rozważania oparto na studiach literatury z zakresu zarządzania oświatą oraz na podstawie wieloletniej obserwacji uczestniczącej.

\section{Szkoła jako specyficzna organizacja publiczna}

Szkoła publiczna funkcjonująca jako organizacja użyteczności publicznej [Bielski, 2002: 35] jest placówką edukacyjną [Flejterska, Rosa, 2005: 535] świadczącą bezpłatne usługi edukacyjne zagwarantowane przez państwo [art. 70. Konstytucji Rzeczypospolitej Polskiej]. Można zatem powiedzieć, że jest specyficzną organizacją publiczną, która działa w interesie publicznym i realizuje cele oraz zadania w zakresie kształcenia, wychowania i opieki szkolnej dzieci, młodzieży i dorosłych poprzez wywieranie wpływu na inne organizacje lub na niezinstytucjonalizowanych uczestników danych społeczności [Kożuch, 2004: 53; 
Bednarska-Wnuk, 2010: 13-16]. W osiąganiu celów bardzo ważną rolę w szkole odgrywają zarówno wykształcona kadra dydaktyczna, rodzice, środowisko [Penc, 2005: 38], jak i warunki techniczno-organizacyjne: baza lokalowa i dydaktyczna [Stankiewicz, 2000: 138].

Specyficzny charakter szkoły z jednej strony kreują zatem zasoby ludzkie, $\mathrm{z}$ drugiej - procesy szkolne, natomiast o specyficznych problemach jej funkcjonowania decydują przedmiot i podmiot oddziaływania [Jarosiewicz, 2004: 443]. Szkoła jako organizacja publiczna realizuje zatem cele społeczne, które, przyjmując za B. Kożuch, mają charakter wielowymiarowy. Wielowymiarowość celów szkoły została pokazana na Rysunku 1.

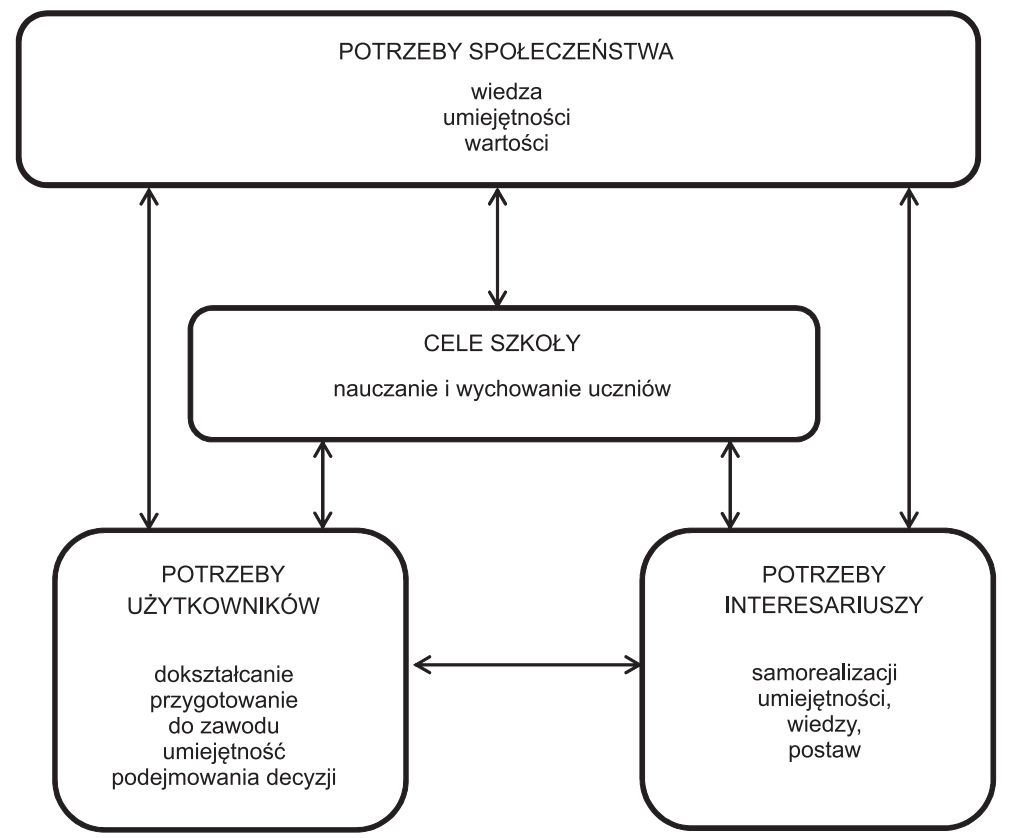

Rysunek 1. Wielowymiarowe cele szkoły

Źródło: opracowanie własne na podstawie: Kożuch, 2004: 93.

Szkołę jako organizację publiczną charakteryzuje zatem większa otwartość na wpływ otoczenia. Wzajemne oddziaływanie na siebie zarówno środowiska zewnętrznego, jak i szkoły, umożliwia dostosowanie jej działalności do rzeczywistych potrzeb publicznych [Kożuch, 2005: 35].

Dla zobrazowania specyficznego charakteru szkoły posłużono się modelem szkoły jako organizacji, który przedstawiono na Rysunku 2. Można zauważyć, że szkoła potrafi zrealizować przyjęte przez siebie cele tylko i wyłącznie wtedy, gdy wykazane w modelu elementy organizacji nie tylko pozostają z sobą w „zależnych związkach", ale też będą oddziaływać na siebie wzajemnie w taki sposób, który przyczyni się do powodzenia całej organizacji [Zieleniewski, 1976: 270-271]. 


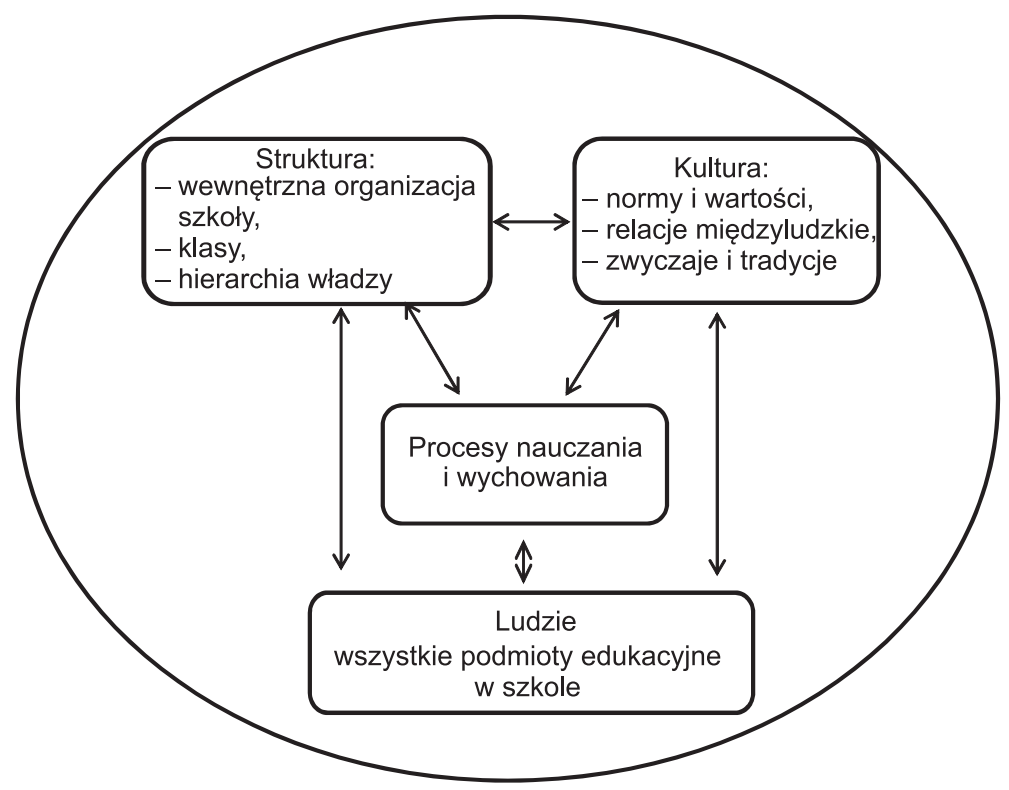

Rysunek 2. Model szkoły jako organizacji

Źródło: opracowanie własne za: Everard, Morris, 1990; Bednarska-Wnuk, 2010: 17; Elsner, Ekiert-Grabowska, Kożusznik, 1997: 9.

Z powyższego sformułowania wynika, że teoretyczną podstawą dalszego rozumowania będzie podejście systemowe do organizacji. Ma ono relatywnie długą historię w myśli z zakresu zarządzania. Podwalin podejścia systemowego dostarczyli dwaj wybitni uczeni: Ludwig von Bertalanffy [1953: 303-361] i Kenneth Boulding [1956: 197 i nast.]. Pojęciowy model teorii systemów jest dziełem Bertalanffy’ego, zasługą Bouldinga było natomiast jego zastosowanie do opisu i objaśniania procesów gospodarczych. Od czasów pierwszych artykulacji teoria (podejście) systemowa doświadczyła pewnej ewolucji, na co zwraca uwagę francuski ekonomista Yvon Pesqueux [2002: 396].

W szczególności rozwinęły się różne metody modelowania, którym przyświecało dążenie autorów do nadania proponowanym metodom „mocy” rozwiązywania złożonych problemów pojawiających się w zarządzaniu [Le Moigne, 1990]. Systemowe modelowanie organizacji wychodzi z kilku fundamentalnych założeń:

- system jest zespołem elementów pozostających we wzajemnej interakcji (elementy te również mogą być systemami - mówimy wówczas o subsystemach);

- pojęciem istotnym dla teorii systemowej jest „relacja”, łącząca z sobą składowe części systemu oraz części z całością i otoczeniem;

- systemy są zorientowane na cele; 
- systemy są otwarte na otoczenie, z którego czerpią zasoby niezbędne dla swego działania (systemy mają ,potrzeby”, które nie mogą zostać zaspokojone bez wymiany z otoczeniem) i do którego kierują swoje własne wytwory, lecz które jest także źródłem nacisków oraz ograniczeń i szans działania;

- systemy odznaczają się występowaniem swoistych sprzężeń zwrotnych, oddziaływaniem „wyjśćc na „wejścia”; sprężenia te mogą stanowić podstawę organizacyjnego uczenia się pod warunkiem, że systemy są wyposażone w środki monitorowania kształtu swoich wewnętrznych i zewnętrznych relacji;

- systemy potrzebują mechanizmów utrzymania równowagi (homeostazy) w swoich relacjach wewnętrznych i zewnętrznych; w sensie empirycznym mechanizmy te to przede wszystkim instrumentarium zarządzania.

Założenia te stały się nie tylko podstawą wielu rozważań teoretycznych i badań. Uformowały również w dużym stopniu rzeczywisty kształt struktur i procesów zarządzania, zaś wielu menedżerów dysponuje dziś bez wątpienia „,systemową wyobraźnią", ilustrującą ich podejście do problemów decyzyjnych. Jednym z mocniejszych argumentów przemawiających za przyjęciem teorii systemowej w niniejszych rozważaniach jest jej zakorzenienie w praktyce zarządzania wielu instytucji.

Yvon Pesqueux pisze o dwóch metodach modelowania: strukturalistycznej i projektującej. Metoda strukturalistyczna ma prowadzić do odpowiedzi na pytanie: „Z czego jest zbudowany system/organizacja?”, zaś metoda projektująca - „Czemu służy dana cecha/własność systemu?” [Pesqueux, 2002: 376]. Metoda strukturalistyczna opiera się na pojęciu efektywności (efficacite), projektująca na pojęciu skuteczności (effectivite). Dociekając efektywności, skupiamy uwagę na jednym kryterium: na relacji zasobów „,skonsumowanych” do zasobów wytworzonych. Natomiast skuteczność wymaga uwzględnienia wielu kryteriów (celów systemu/organizacji), stąd też modelowanie uwzględniające skuteczność lepiej nadaje się do „portretowania” systemów złożonych. Naszym zdaniem, choć nie podejmuje tej kwestii cytowany Pesqueux, są to podejścia raczej komplementarne niż alternatywne. Potrzebujemy zarówno metod diagnozowania kompozycji systemu (organizacja, jej struktury), jak i projektowania jego kształtu. Konieczne są metody diagnostyczne, które poprzedzałyby fazy projektowania systemów (ich przykładem są audyty; większość tzw. list kontrolnych, czyli pytań o dane, zadawanych przez audytorów pod adresem badanej organizacji, ma wyraźnie systemową proweniencję).

Systemy przypominają organizmy żywe pod jednym istotnym względem - wykazują zdolność do trwania i rozwoju. Odznaczają się dynamiką, którą można przyrównać do dynamiki organizmów biologicznych; widać to najwyraźniej wtedy, gdy mowa o ,cyklu życia organizacji” lub kiedy badacze zajmują się „populacyjną ekologią organizacji” [Hannan, Freeman, 1977: 929-964]. Dynamikę tę opisuje się na różne sposoby. Niniejszym przedstawiamy propozycję Y. Pesqueux. Sądzi on, że systemy złożone przechodzą dziewięć poziomów artykulacji: 
- poziom I: system jest identyfikowalny,

- poziom II: system jest aktywny, „działa”,

- poziom III: system jest regulowany,

- poziom IV: system monitoruje swoje działanie,

- poziom V: system decyduje o swoim działaniu,

- poziom VI: system dysponuje pamięcią,

- poziom VII: system koordynuje swoje decyzje o kierunkach działania,

- poziom VIII: system rozważa możliwości podejmowania nowych decyzji,

- poziom IX: system osiąga swoje cele („finalizuje się") [Pesqueux, 2002: 376].

Z każdym „wyższym” poziomem artykulacji (można powiedzieć: dojrzałości systemu) rośnie zdolność do rozwiązywania złożonych problemów, czyli do podejmowania decyzji. Modelowanie systemowe zmierza do precyzyjnego doboru wskaźników dla każdego z tych poziomów i w rezultacie do empirycznej identyfikacji cech systemów. Jest jeszcze inny pożytek z podobnych „konstrukcji”: kierują one uwagę na fazę rozwojową, w której może znajdować się jakiś system lub jego część. Zgodnie z tym - nawet przy tych samych uwarunkowaniach prawnych - dwie różne szkoły mogą, przykładowo, w odmienny sposób wykorzystywać potencjał tkwiący we współdziałaniu z radą rodziców.

Dziedziną, w której najszybciej upowszechniły się pojęcia systemowe, było zarządzanie. Dziś trudno znaleźć podręcznik z tego zakresu, w którym przynajmniej raz nie zostało użyte słowo „system”. Od czasu do czasu słychać głosy, że podejście systemowe już wyczerpało swój intelektualny potencjał i należy odeń odejść. Taką tezę już dość dawno temu (w latach siedemdziesiątych XX wieku) głosił socjolog David Silverman [1970]. Uważał on, że należy porzucić związane z „systemową ortodoksją” schematy myślenia i zastąpić je zupełnie nowym podejściem uwzględniającym działanie jako kategorię analityczną. Podejście systemowe jest nadal żywotne, choć z pewnością nie ma już charakteru dominującej nowości. Przeciwnie - ma wielu konkurentów. Gareth Morgan wymienia następujące alternatywne koncepcje organizacji: model mechanistyczny, organizacja jako mózg, jako kultura, organizacje jako areny polityczne, jako więzienia psychiczne, jako przepływ i transformacja, jako narzędzie dominacji, jako hologram [Morgan, 1997]. Pesquex wskazuje z kolei na takie reprezentacje organizacji, jak: model procesowy, finansowy, ekonomiczny, prawny, model interesariuszy, informacyjny, model sieci, modele taylorowski i post-taylorowski, model kulturowy i wielokulturowy, model systemowy. Podejście systemowe broni się w obliczu tych licznych alternatyw. Broni się także dlatego, że ma znaczenie pomocnicze niemal we wszystkich tych propozycjach; mowa bowiem o organizacji jako „systemie" kulturowym, systemie interesariuszy, systemie prawnym, ekonomicznym itp. Nawet relatywnie nowa metafora sieci daje się wyrazić w kategoriach systemowych (poprzez pojęcie relacji). Uważamy, że pojęcie systemu może nadal odgrywać dużą rolę w refleksji nad zarządzaniem, tym razem jako łącznik między różnymi propozycjami. W kontekście dociekań nad zarządzaniem szkołą podejście systemowe daje się, przykładowo, powiązać z modelem interesariuszy. Ten drugi jest specjalnie wrażliwy na specyfikę zarządzania szkołą, która polega przecież 
na zdefiniowaniu pozycji i funkcji, jakie wobec siebie powinny pełnić szkoła i jej grono interesariuszy. Chodzi zarówno o interesariuszy zewnętrznych, jak i wewnętrznych. Trudność tego podziału polega m.in. na tym, że część interesariuszy szkoły wykazuje „mieszane obywatelstwo” - do takich zaliczyć można radę rodziców. Z jednej strony jest to organ współzarządzania szkołą, z drugiej - reprezentacja interesów grupy zewnętrznej w stosunku do personelu szkoły i uczniów. Podejście systemowe jest pomocne w budowaniu relacji z interesariuszami i w zarządzaniu tymi relacjami. Sugeruje potrzebę wprowadzenia pewnych elementów monitorowania dynamiki interesariuszy (może to być sondaż opinii - w wielu szkołach sondaże takie są już częścią praktyki zarządzania).

Traktowanie szkoły z punktu widzenia systemowego ujęcia organizacji pozwala wyodrębnić pięć podsystemów [Kaczmarek, Sikorski, 1998: 33; Bielski, 2002: 39]. Pierwszym podsystemem jest podsystem celów i wartości, określający kierunki współdziałania, wskazywane zarówno przez państwo, jak i szkołę. Drugim - podsystem techniczny, do którego zaliczymy budynki szkolne wraz z wyposażeniem, technologie informatyczne oraz know-how. Kolejnym wyróżnionym podsystemem jest podsystem struktury, pokazujący podział zadań w szkole, strukturę organizacyjną, podległości służbowe czy delegowanie uprawnień. Czwartym - podsystem psychospołeczny, który obejmuje wszystkich pracowników szkoły zaangażowanych w realizację wyznaczonych celów szkoły. Podsystem zarządzania staje się podsystemem łączącym te cztery wymienione podsystemy i ma bardzo istotny wpływ na właściwe funkcjonowanie szkoły. Umożliwia on placówce oświatowej nie tylko osiąganie wysokiej jakości usług edukacyjnych, ale też stwarza możliwość zaoferowania bogatszej i bardziej różnorodnej oferty dydaktycznej oraz przyczynia się do rozwoju infrastruktury placówki oraz poprawy jej kondycji finansowej. Umiejętne zarządzanie jednostką oświatową wpłynie też na pozycję szkoły na rynku usług edukacyjnych [Szczupaczyński, 2004: 14]. Należy podkreślić, że na zarządzanie szkołą wywierają wpływ z jednej strony przyjęte cele, określane zarówno przez szkołę, jak i przez państwo, społeczeństwo lokalne oraz rodziców i uczniów; z drugiej - przepisy prawa, które znacznie ograniczają funkcjonowanie szkół publicznych [Pielachowski, 2002: 35]. Szczególną rolę w podsystemie zarządzania szkołą odgrywa dyrektor szkoły, który nadaje kierunek działania całej szkole. Wprawdzie jego zadania wynikają z realizacji przepisów zawartych w ustawie o systemie oświaty [art. 39 Ustawy o systemie oświaty], jednak jakość zarządzania powierzoną mu placówką oświatową zależy od jego umiejętności i kompetencji.

\section{Ustawowe kompetencje rady rodziców}

Społecznym organem każdej szkoły jest reprezentacja rodziców [Krajewska, 2009: 16-19], działająca jako rada rodziców. Podstawy do tworzenia i funkcjonowania tego organu wynikają z art. 53 Ustawy z dnia 7 września 1991 roku o systemie oświaty [Dz.U. z 2004 r., Nr 256, poz. 2572 z późn. zm.], Ustawy z dnia 11 
kwietnia 2007 roku o zmianie ustawy o systemie oświaty oraz o zmianie niektórych innych ustaw [Dz.U. z 2007 r., Nr 80, poz. 542] oraz Ustawy Prawo oświatowe [Dz.U. z 2017 r., poz. 59 i 949]. Należy podkreślić, że obowiązująca Ustawa z dnia 14 grudnia 2016 roku Prawo oświatowe daje jeszcze większe uprawnienia radzie rodziców [Dz.U. z 2017 r.]. Ministerstwo Edukacji Narodowej uwzględniło w nowych przepisach postulaty rodziców zrzeszonych w Fundacji „Rodzice Szkole" i wprowadziło korzystny, zdaniem rodziców, zapis dający możliwość przechowywania funduszy rady rodziców na odrębnym rachunku bankowym, a zakładanie, likwidację oraz dysponowanie odrębnym rachunkiem ograniczono wyłącznie do osób posiadających pisemne upoważnienie udzielone przez radę rodziców [Prawo oświatowe, art. 84, ust. 7]. Należy wspomnieć, iż podobny do rady rodziców organ szkoły działał w placówkach edukacyjnych do 2007 roku najczęściej pod nazwą komitet rodzicielski [Jeżowski, 2002: 24; Okoń, 2004: 184; Janus, 2006: 79; Kowolik, 2006: 23; Wolan, 2004: 83]. Niektórzy autorzy używali zamiennie pojęcia „rada rodziców” i „komitet rodzicielski”, przyjmując, że „komitet rodzicielski” jest inaczej radą rodziców, zrzeszającą rodziców oraz prawnych opiekunów uczniów danej placówki edukacyjnej [Rzędowska, 2007: 18], w celu „współdziałania ze szkołą w sprawowaniu funkcji wychowawczych i opiekuńczych" [Okoń, 2004: 184; Krajewska, 2012: 34] oraz ścisłej współpracy z władzami szkolnymi, nauczycielami i uczniami [Janus, 2006: 79]. Od 2007 roku tworzenie rad rodziców w szkołach ma charakter obligatoryjny [Cichocki, 2011: 173], co z jednej strony podnosi rangę rady rodziców [Balicki, Pyter, 2011: 175], z drugiej natomiast skutkuje, jak uważają niektórzy autorzy, tym, iż tworzone są w każdej placówce edukacyjnej, czyli nawet w tych jednostkach, w których nie mogą skutecznie funkcjonować [Dzierzgowska, Rękawek, 2008: 20]. Liczebność rodziców w radzie rodziców zależy od wielkości szkoły. Rada rodziców, przyjmując zgodnie za art. 53, ust. 2 ustawy o systemie oświaty i zakładając, że w skład rady rodziców wchodzą przedstawiciele wszystkich rad klasowych (oddziałowych), może liczyć od kilku do kilkunastu, a nawet kilkudziesięciu członków [Król, Kuzior, Łyszczarz, 2011: 363]. Rada rodziców ma wewnętrzną strukturę, określoną w uchwalonym przez siebie regulaminie [art. 53, ust. 4 Ustawy o systemie oświaty], którą tworzą zazwyczaj: przewodniczący, zastępca, skarbnik, sekretarz oraz komisja rewizyjna. Zdarza się, że w dużych radach rodziców zostają wyodrębnione zespoły zajmujące się konkretnymi zdaniami [Dzierzgowska, Rękawek, 2008: 95]. Wybory do rad rodziców odbywają się corocznie, na pierwszym zebraniu rodziców [Krajewska, 2012: 44; art. 53, ust. 3] na piśmie i w sposób tajny, przy czym prawo głosowania ma rodzic każdego ucznia [Dzierzgowska, Rękawek, 2008: 100]. Niektórzy autorzy zwracają uwagę na procedurę wyborów do rady rodziców, sugerując jednocześnie, aby pomimo dużych trudności wynikających z nieznajomości osób kandydujących poświęcić czas zarówno na krótkie przedstawienie się kandydata, które umożliwiłoby jego poznanie, jak i pozwolić na zadawanie pytań przez pozostałych rodziców. Chodzi bowiem o to, by wybrać przedstawicieli rodziców w sposób odpowiedzialny [Starzyński, Wieczorek, Kołodziejczyk, Kunicki-Goldfinger, 2005: 47]. Wybrana rada rodziców pracuje przez okres jednego roku szkolnego, realizując 
swoje ustawowe zadania według, o czym już wcześniej wspomniano, przyjętego i zatwierdzonego regulaminu rady rodziców [Winczek, 2007: 10; Starzyński, 2007: 23]. Tworzony i uchwalany corocznie regulamin rady rodziców [Dz.U. z 2007 r., Nr 80, poz. 542] jest przygotowany na podstawie dokumentów placówki, z uwzględnieniem specyfiki danej szkoły [Skrobisz-Kaczmarek, 1996: 93], i określa w szczególności cele i zadania przyjęte do realizacji przez radę rodziców, strukturę, tryb pracy, a także zasady wydatkowania zebranych funduszy [Dzierzgowska, Rękawek, 2008: 96].

\section{Wykorzystanie rady rodziców w zarządzaniu szkołą publiczną}

Ustawa z dnia 11 kwietnia 2007 r. o zmianie ustawy o systemie oświaty oraz o zmianie niektórych ustaw, art. 54, rozszerzyła kompetencje rady rodziców, dając jednocześnie możliwość współdecydowania w ważnych sprawach szkoły. Obowiązek współpracy szkoły z rodzicami narzuciły wprowadzone wymagania wobec szkół [Dz.U. z 2009 r., Nr 168, poz. 1324, z późn. zm.]. Już w minimalnym, podstawowym wymaganiu na poziomie „D” przedmiotem badań ewaluacyjnych stały się relacje z rodzicami, poziom ich zaangażowania w życie szkoły oraz partycypacja w zarządzaniu [Koper, Kierzkowska-Żuk, 2016: 107-122; Wroński, 2014: 9]. Profesor Mendel uważa, że wpisane w wymagania relacje rodzice-szkoła nawiązują do koncepcji „szkoły przeźroczystej” [Mendel, 2001], czyli szkoły, w której rodzice uczestniczą we wszystkich procesach zarządzania, także tych dotyczących celów i treści nauczania oraz metod pracy z dziećmi. Niektórzy autorzy podnoszą dużą rolę rodziców i twierdzą, że wiodącymi osobami w edukacji dziecka są właśnie rodzice i dlatego na nich spoczywa główna odpowiedzialność za jej przebieg [Kędra, 2011: 10]. Rada rodziców, stając się obligatoryjnym organem każdej szkoły [art. 53], współuczestniczy w życiu szkoły, m.in. bierze aktywny udział w tworzeniu programu wychowawczego i profilaktyki [Pilich, 2009: 549-550]. Aktywna rada rodziców pełni zatem w szkole różne funkcje, począwszy od funkcji reprezentacyjnej, doradczo-opiniującej czy wspierającej finansowo, na funkcji kontrolująco-nadzorczej skończywszy [Tejszerski, 2009: 10]. Za autorami zajmującymi się problematyką jednego z organów szkoły, jakim jest rada rodziców [Dzierzgowska, Rękawek, 2008: 111-112; Krajewska, 2012: 55], zidentyfikowano następujące obszary oraz kompetencje rady rodziców. Podział ten zilustrowano w Tabeli 1. 
Tabela 1.

Kompetencje rady rodziców

\begin{tabular}{|c|c|}
\hline Obszar/kategoria & Kompetencje \\
\hline Uprawnienia ogólne & $\begin{array}{l}\text { Możliwość wnioskowania: } \\
\text { - do wszystkich organów we wszystkich spra- } \\
\text { wach dotyczących szkoły [art. 54, ust. 1], } \\
\text { - o powołanie rady szkoły [art. 51, ust. 9], } \\
\text { - o nadanie szkole imienia [Dz.U. z 2001 r., Nr } \\
\text { 61, poz. } 624 \text { ze zm.], } \\
\text { - o noszeniu obowiązkowego jednolitego stroju } \\
\text { przez uczniów, } \\
\text { - o zniesieniu noszenia obowiązkowego jedno- } \\
\text { litego stroju przez uczniów. } \\
\text { Uzgadnia z innymi organami wzór jednolitego } \\
\text { stroju [art. 64, ust 1-3]. }\end{array}$ \\
\hline $\begin{array}{l}\text { Uprawnienia dotyczące organizacji trzech } \\
\text { najważniejszych procesów w szkole: } \\
\text { dydaktycznego, wychowawczego } \\
\text { i opiekuńczego }\end{array}$ & $\begin{array}{l}\text { - uchwalanie (wspólnie z radą pedagogiczną) } \\
\text { programu wychowawczego i profilaktycznego } \\
\text { placówki [art. 54, ust. 2], } \\
\text { - opiniowanie form realizacji zajęć wychowa- } \\
\text { nia fizycznego oraz dodatkowych dni wolnych } \\
\text { od zajęć dydaktyczno-wychowawczych [Dz.U. } \\
\text { z } 2012 \text { r., Nr } 175 \text { poz. 1042; Dz.U. z } 2012 \text { r., poz. } \\
204 \text { ze zm.], } \\
\text { - wyrażanie zgody na funkcjonowanie w szkole } \\
\text { innych organizacji [art. 56, ust. 2], } \\
\text { - opiniowanie formy działalności dydaktyczno- } \\
\text {-wychowawczej [art. 64], } \\
\text { - wspieranie zespołu powypadkowego w spra- } \\
\text { wie ustalenia przyczyn wypadku oraz udział } \\
\text { w wypracowywaniu sposobu zapobiegania } \\
\text { podobnym wypadkom, } \\
\text { - ocenianie uczniów odnośnie do ich zacho- } \\
\text { wania oraz udział w komisji ustalającej roczną } \\
\text { ocenę kwalifikacyjną z zachowania ucznia } \\
\text { (w przypadku wniesionych zastrzeżeń odnoszą- } \\
\text { cych się do zachowania ucznia) }\end{array}$ \\
\hline Uprawnienia dotyczące nadzoru & $\begin{array}{l}\text { - opiniowanie programów poprawy efektywno- } \\
\text { ści kształcenia lub wychowania, } \\
\text { - zapoznanie się z przygotowanym przez dyrek- } \\
\text { tora planem nadzoru [art. 54, ust. 2] }\end{array}$ \\
\hline Uprawnienia dotyczące spraw kadrowych & $\begin{array}{l}\text { - opiniowanie oceny dorobku nauczycieli [art. } \\
\text { 9c, ust 6-7 Karty Nauczyciela], } \\
\text { - wnioskowanie o ocenę pracy nauczyciela [art. } \\
\text { 6a, ust. 1 Karty Nauczyciela], } \\
\text { - udział przedstawiciela rady rodziców w ze- } \\
\text { spole odwoławczym oceny pracy nauczyciela, } \\
\text { - udział w zespole odwoławczym rozpatru- } \\
\text { jącym wniosek o ponowną ocenę dyrektora } \\
\text { szkoły, } \\
\text { - udział w konkursie wyboru dyrektora szkoły } \\
\text { [art. 36a, ust. 9, pkt 2] }\end{array}$ \\
\hline
\end{tabular}




\begin{tabular}{|l|l|}
\hline Uprawnienia dotyczące spraw finansowych & $\begin{array}{l}\text { - opiniowanie planów finansowych opracowa- } \\
\text { nych przez dyrektora placówki, }\end{array}$ \\
& $\begin{array}{l}\text { gromadzenie i wydatkowanie środków finan- } \\
\text { sowych [art. 54, ust. 8], } \\
\text { - możliwość otwierania odrębnego rachunku } \\
\text { bankowego [art. 84, ust. 7 Prawo oświatowe] }\end{array}$ \\
\hline
\end{tabular}

Źródło: opracowanie własne na podstawie: Dzierzgowska, Rękawek, 2008; Krajewska, 2012; Tymków, Gawryluk, 2017.

Zestawione w Tabeli 1 kompetencje rady rodziców można, ze względu na ich treść, podzielić na:

kompetencje stanowiące, takie jak m.in.:

- uchwalanie regulaminu własnej działalności [art. 53, ust. 4],

- uchwalenie (wspólnie z radą pedagogiczną) programu wychowawczego i programu profilaktyki [art. 54, ust. 4],

- wnioskowanie o wprowadzenie, zniesienie noszenia oraz uzgadnianie $\mathrm{z}$ innymi organami szkoły wzoru jednolitego stroju [art. 64],

- delegowanie przedstawiciela do komisji konkursowej powołanej w celu wyboru dyrektora szkoły [art. 36a],

oraz kompetencje opiniodawcze, dające możliwość opiniowania np. w zakresie decyzji dotyczących planu finansowego szkoły [art. 54, ust. 2], poprawy efektywności kształcenia i wychowania [art. 56, ust. 2], a także oceny pracy zarówno nauczyciela, jak i dyrektora szkoły [art. 6a, ust. 3; Wroński, 2014: 12-13].

Analizując uprawnienia rady rodziców, zauważono także, że dotyczą one wszystkich obszarów funkcjonowania szkoły, przy czym zwrócono uwagę, że działalność w jednych obszarach wynika wyłącznie z inicjatywy rady rodziców, a więc może być podejmowana przez radę rodziców lub nie, w innych natomiast - jest konsekwencją obowiązku ustawowego. Przedstawione zatem kompetencje rady rodziców, o czym już wspomniano, mogą dotyczyć zarówno wydawania opinii, czego przykładem może być m.in. opiniowanie oceny dorobku zawodowego nauczycieli - stażystów, nauczyciela kontraktowego i mianowanego, współdecydowania - tj. wspólnego ustalania programu wychowawczo profilaktycznego, jak i rozstrzygania, np. w sprawie wydatków zgromadzonych zasobów finansowych. Rada rodziców, przy założeniu współdziałania dwóch stron - szkoły, którą reprezentuje dyrektor, i rodziców, których reprezentantem jest właśnie rada rodziców, może wspierać dyrektora placówki w skutecznym zarządzaniu. Wybrane działania rady rodziców wspierające różne funkcje zarządzania przedstawiono w Tabeli 2. 
Tabela 2 .

Rada rodziców a zarządzanie szkołą

\begin{tabular}{|l|l|}
\hline Funkcja zarządzania & Działania rady rodziców \\
\hline Planowanie & $\begin{array}{l}\text { Zdiagnozowanie potrzeb i oczekiwań rodziców, przeprowadzenie ankiety } \\
\text { wśród rodziców i uczniów, pomoc w budowaniu strategii rozwoju szkoły, } \\
\text { propozycja ciekawych zajęć pozalekcyjnych. }\end{array}$ \\
\hline Organizowanie & $\begin{array}{l}\text { Pomoc w organizowaniu ciekawych wycieczek pozwalających na pozna- } \\
\text { nie np. przyrody, krajobrazu, specyfiki regionu, funkcjonowania różnych } \\
\text { organizacji, organizacji pracy w zakładach pracy; zapraszanie ciekawych } \\
\text { osób bądź wystąpienie rodzica w roli eksperta, włączenie się w działal- } \\
\text { ność opiekuńczo-wychowawczą, współorganizowanie imprez integracyj- } \\
\text { nych rodzice-uczniowie-nauczyciele, udział w projektach. }\end{array}$ \\
\hline Motywowanie & $\begin{array}{l}\text { Organizowanie konkursu na najlepszego nauczyciela w szkole; zorganizo- } \\
\text { wanie szkolenia dla nauczycieli. }\end{array}$ \\
\hline Kontrolowanie & $\begin{array}{l}\text { Informowanie dyrektora o niezadowoleniu uczniów, rodziców np. z pracy } \\
\text { nauczyciela, opiniowanie pracy nauczycieli. }\end{array}$ \\
\hline
\end{tabular}

Źródło: opracowanie własne.

Radę rodziców cechuje duża heterogeniczność jej członków. Rodzice wchodzący w skład rady rodziców są często ludźmi wpływowymi, mającymi duże możliwości wspierania czy też inicjowania ciekawych zajęć organizowanych przez szkołę. Reprezentują bowiem różne zawody, pełnią różne role społeczne poza szkołą, zajmują czasami wysokie stanowiska. Często posiadają szerokie kontakty prywatne i zawodowe. Umiejętne wykorzystanie kapitału rodziców może przyczynić się zatem zarówno do skutecznego zarządzania placówką oświatową, uatrakcyjnić procesy dydaktyczne, wspomóc procesy wychowawcze i opiekuńcze, jak i umożliwić nauczycielom wymianę doświadczeń. Z licznych opracowań wynika, że tam, gdzie rodzice aktywnie uczestniczą w życiu szkoły, współdecydują o podejmowanych decyzjach, osiągają lepsze rezultaty w obszarze dydaktyki oraz wykazują efektywniejsze działania w zakresie wychowania [Kędra, 2011; Koper, Kierzkowska-Żuk, 2016; Murawska, 2014].

\section{Zakończenie}

Zmiana ustawowa wprowadzona w 2007 roku wzmocniła pozycję rady rodziców i postawiła ją na równi z innymi organami szkoły. Rada rodziców, będąca reprezentantem rodziców uczniów danej szkoły, umożliwia wszystkim rodzicom kontaktowanie się z pozostałymi organami szkoły, a przede wszystkim z dyrektorem placówki. Można zatem uznać, że jej funkcjonowanie, aktywność, a także współpraca ze szkołą są przejawami demokratyzacji szkoły. Dopuszczenie do głosu rodziców, czyli osób najbardziej zainteresowanych rozwojem, wychowaniem i edukacją swoich dzieci, umożliwia szkole wykorzystanie dużego 
potencjału ludzkiego, który pozwala nie tylko budować pozytywny wizerunek szkoły w otoczeniu, ale także może uporządkować informację, ułatwić organizację pracy szkoły, wzmocnić decyzyjność oraz pogłębić motywację pracy nauczycieli i uczniów. Tylko aktywna, mądra i skuteczna rada rodziców może rozbudzić entuzjazm rodziców do zaangażowania się w życie szkoły oraz służyć wsparciem dla dyrektora i nauczycieli.

\section{Bibliografia}

Balicki A., Pyter M. (2011), Prawo oświatowe, Wydawnictwo C.H. Beck, Warszawa.

Bednarska-Wnuk I. (2010), Zarządzanie szkoła XXI wieku. Perspektywa menedżerska, Wydawnictwo ABC a Wolters Kluwer business, Warszawa.

Bertalanffy L. (1953), General System Theory: A New Approach to Unity of Science, „Human Biology", vol. 23, grudzień.

Bielski M. (2002), Podstawy teorii organizacji i zarządzania, Wydawnictwo C.H. Beck, Warszawa.

Boulding K. (1956), General system theory, a skeleton of science, „Management Science”, vol. 2, nr 3, kwiecień.

Cichocki A. (2011), Świadomość możliwości wpływu rodziców na edukację dzieci i środowisko szkolne jako impuls nowej strategii pracy szkoty [w:] A. Karpińska, K. Borawska-Kalbarczyk (red.), Horyzonty rozwoju edukacji w dialogu i perspektywie, Difin, Warszawa.

Dzierzgowska I., Rękawek A. (2008), Rada rodziców - sposoby skutecznego działania w szkole. Niezbędnik aktywnego rodzica, Wydawnictwo ABC a Wolters Kluwer business, Warszawa.

Dzierzgowska I., Rękawek A. (2008a), Wszystko o radach rodziców. Niezbędnik dyrektora, Wydawnictwo ABC a Wolters Kluwer business, Warszawa.

Elsner D., Ekiert-Grabowska D., Kożusznik B. (1997), Jak doskonalić pracę dyrektora szkoty?, Materiaty do samoksztatcenia, część III, Kierowanie szkoła, Wojewódzki Ośrodek Metodyczny w Katowicach, Katowice.

Everard K.B., Morris G. (1990), Effective School Management, SAGE Publications, London.

Flejterska E., Rosa G. (2005), Ustugi edukacyjne [w:] S. Flejterski, A. Panasiuk, J. Perenc, G. Rosa, Współczesna ekonomika usług, PWN, Warszawa.

Hannan M.T., Freeman J. (1977), The Population Ecology of Organizations, „American Journal of Sociology", vol. 82, nr 5, marzec.

http://www.radyrodzicow.pl/index.php/86-aktualnosci/219-korzystne-zmiany-dla-rad-rodzicow-w-ustawie-prawo-oswiatowe [dostęp: 20.08.2017].

Janus K. (2006), Pedagogika i psychologia. Zagadnienia, pojęcia, terminy, Wydawnictwo Buchmann, Warszawa.

Jarosiewicz H. (2004), O specyfice pojęcia sukcesu w kierowaniu placówkami oświatowymi [w:] T. Listwan (red.), Sukces w zarzadzaniu kadrami. Pespektywa globalna i lokalna, Prace Naukowe Akademii Ekonomicznej we Wrocławiu, nr 1032, Wydawnictwo Akademii Ekonomicznej im. Oskara Langego we Wrocławiu, Wrocław. 
Jeżowski A. (2002), Po co komu rada rodziców?, „Dyrektor Szkoły”, nr 1.

Kaczmarek B., Sikorski C. (1998), Podstawy zarzadzania. Zachowania organizacyjne, Przedsiębiorstwo Specjalistyczne „Absolwent”, Łódź.

Kędra M. (2011), Właczanie rodziców w edukację dzieci, Ośrodek Rozwoju Edukacji, Warszawa.

Konstytucja Rzeczypospolitej Polskiej.

Koper A., Kierzkowska-Żuk I. (2016), Udział rodziców w życiu szkoły, „Studia i prace pedagogiczne. Rozprawy i materiały. Pedagogika”, 3.

Kowolik P. (2006), Rada rodziców [w:] T. Pilch (red.), Encyklopedia pedagogiczna XXI wie$k u$, t. V, PWN, Warszawa.

Kożuch B. (2004), Zarzadzanie publiczne. W teorii i praktyce polskich organizacji, Wydawnictwo PLACET, Warszawa.

Kożuch B. (2005), Specyficzne cechy organizacji publicznej [w:] B. Kożuch, T. Markowski, Z teorii i praktyki zarzadzania publicznego, Fundacja Współczesne Zarzadzanie, Białystok.

Krajewska B. (2009), Instytucje wsparcia dziecka i rodziny. Zagadnienia podstawowe, Oficyna Wydawnicza „Impuls”, Kraków.

Krajewska B. (2012), Rada rodziców w szkole, Wydawnictwo Edukacyjne „Akapit”, Toruń.

Król A., Kuzior P., Łyszczarz M. (2011), Prawo oświatowe. Komentarz do ustawy o systemie oświaty, Wydawnictwo ParkPrawo, Warszawa-Bielsko-Biała.

Le Moigne J.-L. (1990), La modélisation des systèmes complexes, Dunod, Paris.

Mendel M. (2011), Rodzice w edukacji. Partnerskie współdziałanie: szkoła miejscem budowania kapitału społecznego, Ks.mkidn.gov.pl/media/srks-rozne/20110520-nr4.pdf [dostęp: 20.08.2017].

Mendel M. (1998), Rodzice i szkoła: jak współuczestniczyć w edukacji dzieci?, Wydawnictwo Adam Marszałek, Torun.

Mendel M. (2001), Edukacja społeczna. Partnerstwo rodziny, szkoły i gminy w perspektywie amerykańskiej, Wydawnictwo Adam Marszałek, Toruń.

Morgan G. (1997), Obrazy organizacji, PWN, Warszawa.

Murawska B. (2014), Edukacja wczesnoszkolna. Wiek 5/6-8/9 lat. Niezbędnik dobrego nauczyciela, seria III, t. 3: Edukacja w okresie dzieciństwa i dorastania, Instytut Badań Edukacyjnych, Warszawa.

Okoń W. (2004), Nowy słownik pedagogiczny, Wydawnictwo Akademickie „Żak”, Warszawa.

Penc J. (2005), Sztuka skutecznego zarzadzania, Oficyna Ekonomiczna Grupa Wolters Kluwer, Kraków.

Pesqueux Y. (2002), Organisations: modèles et représentations, Presses Universitaires de France, Paris.

Pielachowski J. (2002), Organizacja i zarządzanie oświata i szkoła, wyd. III, Wydawnictwo eMPi2, Poznań.

Pilich M. (2009), Ustawa o systemie oświaty. Komentarz, Wydawnictwo ABC a Wolters Kluwer business, Warszawa.

Rozporzadzenie Ministra Edukacji Narodowej z dnia 21 maja 2001 r. w sprawie ramowych statutów publicznego przedszkola oraz publicznych szkót (Dz.U. z 2001 r., Nr 61, poz. 624 ze zm.), par. 1, ust. 4. 
Rozporządzenie Ministra Edukacji Narodowej z dnia 6 sierpnia 2015 r. w sprawie wymagań wobec szkół i placówek (Dz.U. z 2015 r., poz. 1214).

Rozporządzenie Ministra Edukacji Narodowej z dnia 7 lutego 2012 r. w sprawie ramowych planów nauczania w szkołach publicznych (Dz.U. z 2012 r., poz. 204 ze zm.), par. 3, ust. 2.

Rozporządzenie Ministra Edukacji Narodowej z dnia 7 października 2009 r. w sprawie nadzoru pedagogicznego (Dz.U. z 2009 r., nr 168, poz. 1324, z późn. zm.).

Rozporządzenie Ministra Edukacji Narodowej z dnia 9 sierpnia 2011 r. w sprawie dopuszczalnych form realizacji obowiązkowych zajęć wychowania fizycznego (Dz.U. z 2011 r., Nr 175, poz. 1042), par. 3, ust. 2.

Rzędowska A. (2007), Rada rodziców, „Wszystko dla Szkoły”, nr 12.

Silverman D. (1970), The Theory of Organisations, Heinemann Educational, London.

Skrobisz-Kaczmarek B. (1996), Ustawa o systemie oświaty z komentarzem, Wydawnictwo Pedagogiczne ZNP, Kielce.

Stankiewicz L. (2000), Słownik organizacji i kierowania w oświacie, Wydawnictwo Adam Marszałek, Toruń.

Starzyński W. (2007), Faktyczna obecność. Jak powołać i poprowadzić radę rodziców, Wydawnictwo Centralnego Ośrodka Doskonalenia Nauczycieli, Warszawa.

Starzyński W., Wieczorek E., Kołodziejczyk W., Kunicki-Goldfinger M. (2005), Prawa rodziców w szkole, wyd. 2, Wydawnictwo STO, Warszawa.

Szczupaczyński J. (2004), Edukacja a zarządzanie: podręcznik akademicki, Wyższa Szkoła Humanistyczna, Pułtusk.

Szklarczyk J., Prawo wewnątrzszkolne. Rada rodziców w szkole, http://www.forumradrodzicow.pl/wp-content/uploads/2015/01/Prawo-wewn\%C4\%85trzszkolne.-Rada-rodzic\%C3\%B3w-w-szkole.pdf [dostęp: 20.08.2017].

Tejszerski R. (2009), Wpływ rad rodziców na życie warszawskich szkót, „Gazeta Szkolna”, $\mathrm{nr} 41$.

Tymków B., Gawryluk J. (2017), Rada rodziców - regulacje prawne. Opracowanie w ramach projektu „Partnerska szkoła”. Uczniowie-nauczyciele-rodzice, http://serwer1423016.home.pl/autoinstalator/wordpress1/wp-content/uploads/2010/09/2.pdf [dostęp: 20.08.2017].

Ustawa z dnia 11 kwietnia 2007 r. o zmianie ustawy o systemie oświaty oraz o zmianie niektórych ustaw (Dz.U. z 2007 r., Nr 80, poz. 542).

Ustawa z dnia 14 grudnia 2016 r. Prawo oświatowe (Dz.U. z 2017 r., poz. 59 i 949).

Ustawa z dnia 7 września 1991 roku o systemie oświaty (Dz.U. z 2004 r., Nr 256, poz. 2572 z późn. zm].

Ustawa z dnia 26 stycznia 1982 r. - Karta Nauczyciela (Dz.U. z 2014 r., poz. 191 ze zm.].

Winczek J. (2007), Rada rodziców w szkole, „Wychowawca”, nr 9.

Wolan T. (2004), Nauczyciel jako wychowawca i współtwórca przemian w edukacji, Biuro Wydawnictw i Upowszechnień „Kontrakt”, Chorzów.

Wroński M. (2014), Szkoła wspótpracy. Uczniowie i rodzice kapitałem społecznym nowoczesnej szkoły. Materiaty szkoleniowe dla rodziców, Fundacja Rozwoju Demokracji Lokalnej, Warszawa.

Zieleniewski J. (1976), Organizacja i zarządzanie, wyd. V, PWN, Warszawa. 